DOI 10.4467/2543733XSSB.17.029.8327

KATARZYNA KROPIAK

Jagiellonian University

\title{
THE POLITICS OF NATION - BUILDING IN KOSOVO AFTER 2008
}

Key words: Nation-Building, State-Building, Norm-Promotion, International Norms, NGOs.

The Republic of Kosovo self-declared independence from Serbia on 17 February 2008. The country has been recognized by most of the member states of the European Union and the United Nations. In its advisory opinion the International Court of Justice was holding that Kosovo's declaration of independence was not in violation either of the general principles of international law or any specific international norms. The system of the new Republic was built on the Comprehensive Proposal for the Kosovo Status Settlement under the Supervision of UNMIK (United Nations Interim Administration Mission in Kosovo).

New democratic institutions were launched within the proclamation of the new republic. Kosovo transferred a the one-party system to a multi-party democracy and from a centrally directed economy to a free-market economy. In a state that had never developed a democratic tradition, legislation was introduced based on a catalogue of international norms and standards: multi ethnicity and respect for minority rights, the rule of law, equality of all citizens, respect for minority rights and human rights and freedoms and constitutionality of the application of law and a free market economy.

This article will describe the problems of Nation - Building in the war-shattered country which is still dealing with problems of the ethnical division, reconstruction of the infrastructure after the war. This article will also explore the problems and the pathology of democracy during the transformation period. International norms are transferred to the local meaning during a three stages process: the promotion of international norms, the contestation of norms and acceptance, rejection or localization in the domestic law system. These indicators will serve the activities of the NGOs in the territory of new country, local initiative and the legislation system of the Republic of Kosovo. Norms are transmitted by peacebuilding agents together with local NGOs and political elites of war-shattered countries. The issue which often occurred in the stage of State-Building and Nation-Building in the post-conflict countries is the rejection of international norms, which are incompatible with domestic tradition and the indigenous law system. The action of the peacebuilder

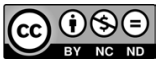


agents are often met with resistance by some social groups therefore requires a very gentle approach, especially for issues that have proved to be a source of previous conflict. These same situations happened in the Republic of Kosovo which struggled with lots of problems of the democratic system, week-economy and the problems with the minority laws and integrity of the society.

\section{Kosovo conflict}

In the 1990 s only 8 out of 110 armed conflicts around the world were conflicts between states. Of these the majority were going on between 'subgroups', national minorities, excluded ethnic groups etc. These groups were raising their demands due to the right of national self-determination ${ }^{1}$. In the contemporary political discourse about the Kosovo conflict we frequently use terms referring to the stabilization of the situation in region. Although war in Kosovo started in 1999, the conflict in this region has a much longer history. The long term Ottoman occupation of the region contributed to the commingling of ethnicities and other national creating factors hadn't created the same impact for the different ethnic groups. Religion, for example, was one factor which had a crucial influence on the constituted Serbian identity while for the Albanians this factors was language. At the end of the $19^{\text {th }}$ century national myths were being created in the process of National Awakening ${ }^{2}$. The Treaty of London in 1913 and the Protocol of Florence decided that the territory of Kosovo will remain outside the Principality of Albania, against the unilateral arrangements of the Congress in Vlore. At the time the ethnic structure wasn't homogeneous ${ }^{3}$. Over the next century the territory was a divisive area. After the collapse of Yugoslavia, Albanians living in Kosovo strengthened their requests for independence. After the reform of the Socialist Federal Republic of Yugoslavia in 1974 Kosovo gained the autonomous status of the Socialist Autonomous Province of Kosovo - 'and Metohija' was removed from the name. Kosovo was granted major autonomy within the SFR Yugoslavia and an autonomous government, separate administration, assembly and some part of the juridical system was established ${ }^{4}$. In the 1980 s, separatist and nationalistic atmosphere among intellectualist elites in the SFR Yugoslavia was growing, causing the exacerbation of conflicts between the Albanian and Serb population ${ }^{5}$. The Albanian community sought to further

${ }^{1}$ E. K. Jenn e, Ethnic Bargaining: The Paradox of Minority Empowerment, New York 2007, p. 1.

2 A. Smith claimed that the myth of origin (mytheteur) was of crucial importance in the process of creating the national identities, A. D. S m it h, Ethnic Origins of the Nations, Oxford 1988.

3 There is a serious dispute between Serbian and Albanian authors and historians when the Albanian settlement began in the territory of the present Kosovo. Danuta Gibas -Krzak in the monography Serbian-Albanian Kosovo conflict in the twentieth century: conditions, course, consequences writes that in the fourteenth century Albanian settlements were in the west and south-west part of Kosovo. Albanians accounted for about $2 \%$ of the population in Kosovo at that time. D. Gib as-Krzak, Serbsko-albański konflikt o Kosowo wX XXieku: uwarunkowania, przebieg, konsekwencje, Toruń 2009, p. 19.

${ }^{4}$ Independent International Commission on Kosovo, The Kosovo report: conflict, international response, lessons learned, New York 2000, pp. 35-36.

${ }^{5}$ For the purposes of article the Serbian - Albanian conflict was just briefly summarize, Insightful analysis of the causes of the Serbian- Albanian conflict in the 1968-1998 describes also the involvement of elites and social and political changes, which had aggravated the situation. See Article, M. Kor zen i ew s ka-W is z- 
increase the autonomy of the region while Serbians wanted to strengthen relations with SFR Yugoslavia. The Serbian population complained of discrimination on the part of the local government while the Albanian section of community demanded further autonomy. Protests by Albanians in Prishtina and Mitrovica in 1981 over the status of Kosovo resulted with the introduction of a state of emergency in the Kosovo with violent protests and the introduction of territorial defence forces to the territory of the autonomic province . $^{6}$ The Milošević government didn't want to agree using populist and nationalistic arguments. In the following years, the Serbian minority in the province decreased, due to a high birth rate among Albanians. Religion started to be next moot point - in 1986 the Serbian Orthodox Church published an official announcement that Kosovo Serbs were being subjected to an Albanian program of 'Genocide' outbreaks against SFR Yugoslavia authorities during all of 1980 resulting in a further increases in emigration of the Serb minority and other ethnic groups, which significantly changed the ethnical proportion in the province. The newly appointed President of Serbia within SFR Yugoslavia Slobodan Milošević in the speech given in the Gazimestan in the $600^{\text {th }}$ anniversary of the Battle of Kosovo claimed: 'Serbs have never in the whole of their history conquered and exploited others. Their national and historical being has been liberational throughout the whole of history and through two world wars, as it is today. They liberated themselves and when they could they also helped others to liberate themselves ${ }^{\text {. }}$. In the testimony given to International Criminal Tribunal for the former Yugoslavia Slobodan Milošević claimed the interpretation of the speech as presaging the armed conflict during the collapse of Yugoslavia was a misunderstanding and misinterpretation $^{9}$. The breakup of Yugoslavia resulted in a series of political upheavals and conflicts during the early 1990s and during this time Kosovo did not gain the same independence other provinces did and instead found the autonomy of Kosovo further limited. In 1992 the Assembly of Kosovo, which didn't recognize the decision coming from Belgrade, declared a sovereign state and elected Ibrahim Rugova as its president ${ }^{10}$. The self-declared republic, during its lifetime, wasn't recognized by any state other than Albania and it was formally disbanded in 2000 after the Kosovo conflict and the established Joint Interim Administration by the United Nations Interim Administration Mission in Kosovo (UNMIK). The reforms introduced after the change of the Constitution threatened the wide autonomy of Kosovo's Albanian. Changes in the national media system and subordination of the media in the province autonomous to Belgrade resulted in shutting down Kosovo's radio and television. The introduction of the reform of the national industrial factories led to an

n iew ska, Geneza konfliktu serbsko-albańskiego w Kosowie w latach 1968-1998 na tle wewnętrznej polityki jugosłowiańskiej - próba analizy, [in:] Studia z dziejów Rosji i Europy Środkowo-Wschodniej, v. XLIII, P. Łossowski (ed.), Warszawa 2008, p. 195-219.

${ }^{6}$ Ibidem, p. 36.

7 See more in: C. R. Prentiss, (ed.), Religion and the Creation of Race and Ethnicity: An Introduction, New York 2003.

${ }^{8}$ Quote from the English translation by the National Technical Information Service of the US Department of Commerce. Reprinted in H. Krieger, (ed.), The Kosovo Conflict and International Law: An Analytical Documentation 1974-1999, Cambridge 2012, pp. 10-11.

${ }^{9}$ International Criminal Tribunal for the former Yugoslavia, IT020214, http://www.icty.org/x/cases/slobodan_milosevic/trans/en/020214IT.htm, (date accessed: 09.12.2016).

${ }^{10}$ N. Malcol m, A Short History of Kosovo, New York 1999, pp. 346-347. 
Albanian workers strike. In the beginning of the 1990's Yugoslavia experienced massive redundancies across the country. Albanians claimed that this reform was specially directed against this minority group. The cause célèbre was an educational system reform, which drastically limited teaching in the languages of the minorities and this led to dismissal of the Albanian academic teachers from the University of Prishtina. Between 1996-1999 the Kosovo Liberation Army - UÇK (Ushtria Çlirimtare e Kosovës) had started to present signs of armed resistance to Yugoslav security forces, which culminated in the Kosovo War. A resolution similar to the Dayton Agreement which ended the Bosnian War in 1995 was expected by Kosovar Albanians to be bring a solution to their situation however the situation in Kosovo remained largely unaddressed by the international community. The escalation towards civil war in Kosovo occurred in January of 1999 after the Račak massacre ${ }^{11}$, the failure of the Rambouillet Accords ${ }^{12}$ by refusing to accept the restoring of the autonomy of Kosovo by Yugoslavia and introducing NATO peacebuilders. This led to the NATO intervention and bombing of Yugoslavia between 24 March and 10 June 1999, which finally had made Milošević withdraw forces from the territory of Kosovo. During the NATO intervention, the Operation Allied Forces didn't have the legitimisation of the Security Council of the United Nation as Russia and China would have never agreed to the intervention. This resulted in numerous controversies due to the intervention of external power in the sovereignty of the state which is contradictory to Article 2 of the United Nations Charter ${ }^{13}$. Some of the interpreters called the Operation Allied Forces the first of the humanitarian operation in the history of the NATO and justified the armed intervention for the sovereignty of the state in order to prevent a humanitarian crisis ${ }^{14}$.

\section{Crisis management in Kosovo}

On 10 June 1999 the UN Security Council passed UN Security Council Resolution 1244 which established Kosovo under transitional UN administration UNMIK (United Nations Interim Administration Mission in Kosovo) and authorised the KFOR (Kosovo Force), NATO's mission aimed at peacebuilding in the Kosovo region. EULEX (European Union Rule of Law Mission in Kosovo) was established on 4 February 2008 as an European Union police and civilian resources for Kosovo.

On 17 February 2008 the Republic of Kosovo declared independence and progressively more than 100 countries recognized Kosovo as an independent country ${ }^{15}$. In an advisory

${ }^{11}$ C. Rog e 1, Kosovo: Where It All Began, International Journal of Politics, Culture, and Society, Vol. 17, $1 / 2003$, p. $167-182$.

12 Fatos Lubonja, publicist from Kosovo point out that to the failure of negotiations contributes the incompatibilities of the multilateral diplomacy procedures, F. L u b o n j a, Neocolonialism and Responsibility, The Western Presence in the Balkans, Eurozine 14/02/2002, http://www.eurozine.com/articles/2002-02-14-lubonjaen.html, (date accessed: 14.03.2014).

13 The Charter of the United Nation, San Francisco 26 June 1945, http:/www.un.org/en/charter-united-nations/index.html, (date accessed: 14.03.2014).

${ }^{14}$ Nowa jakość konfliktów zbrojnych na przełomie XX i XXI wieku. Przyczyny - uwarunkowania - skutki, [in:] W. Malendowski (ed.), Zbrojne konflikty i spory międzynarodowe u progu XXI wieku, Wrocław 2003, pp. 37-38, M. Mars załek, Sojusznicza operacja "Allied Force”: przebieg - ocena - wnioski, Toruń 2009, pp. $217-226$.

15 20.05.2015 Antigua and Barbuda was $111^{\text {th }}$ country which recognized the Republic of Kosovo. 
opinion the International Court of Justice by the UN General Assembly regarding the 2008 Kosovo declaration of independence declared that 'the adoption of the declaration of independence on the 17 February 2008 did not violate general international law because

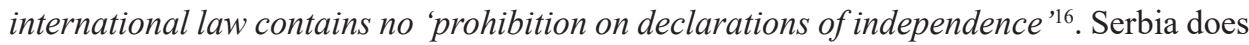
not recognize the Republic of Kosovo. The part of the Serb-inhabited territory largely opposed the declaration of the independence formed the Assembly of the Community of Municipalities of the Autonomous Province of Kosovo and Metohija.

Over the years the Kosovo conflict was managed by many missions, institutions of the multilateral diplomacy, International forces and International Non-Government Organizations and this help was focused in every sectors of the politics. The ICO (International Civilian Office) and ICR (International Civilian Representative for Kosovo) were responsible for the implementation of the Ahtisaari Plan, promoting good governance, democratic standards and rule of the law ${ }^{17}$. EULEX was established to ensure support and assistance of the police and the prosecutor's office. Many other missions and organizations deeply interfered in the structures of the new formed state, however sections of society were not so accommodating with the presence of the stabilization mission. The Vetëvendosje (Self-Determination) Movement (which in the election of 2010 gained $12.66 \%$ votes) highly criticized the UN presence in Kosovo and campaigned for the sovereignty exercised by the people instead mainly by organizing street protests and drawing political graffiti.

Today The main problem of Kosovo is poverty and high levels of unemployment. Various efforts to combat these problems have been undertaken and various initiatives have been raised such as the Program of experience exchange, founded by World Bank in the field of energy called 'New Kosovo'. Many INGOs established their offices in Kosovo and run programs designed to build good practise of Citizen Participation. In addition many local initiatives should also be distinguished.

\section{Politics of the Nation-Building}

The complexity of the situation in Kosovo required a multilevel approach which recognized various factors and indicators of the conflict, historical, religious, ethnicity, cultural as well as economics and legal factors. The conflict in Eastern Europe which turned into a civil war could not remain only a local issue but instead required a reaction from the international community. The Experiences of foreign forces in Kosovo show that the opinions and attitudes of locals towards the peace building practises can be very diversified. The complexity of the solutions which ranged from bombing raids and ended with the exchange of experiences in the field of energy or citizen participations shows that

\footnotetext{
${ }^{16}$ Accordance with international law of the unilateral declaration of independence in respect of Kosovo, International Court of Justice 2010-07-22. p. 4, http://www.icj-cij.org/docket/files/141/15987.pdf (date accessed: 15.03.2014).

17 Letter dated 26 March 2007 from the Secretary-General addressed to the President of the Security Council, Addendum, Comprehensive Proposal for the Kosovo Status Settlement, United Nations Security Council, 26 March 2007, http://www.unosek.org/docref/Comprehensive_proposal-english.pdf (date accessed: 15.03.2014).
} 
global processes should have their limits. At present when the Kosovo conflict enters into the field of international affairs it is permanently govered by different centres of decision making. Even local problems need to be solved according to the line of multilateral diplomacy and international organizations.

After the declaration of the independence in 2008 there was another important issue to declare - the national identity of citizens of new-established Republic of Kosovo. Kosovo's ethnic composition changed significantly over the last century. At present, Albanians are the largest ethnic group living in the new Republic. These Kosovars ${ }^{18}$ speak a dialect of the Albanian language and their home country is not Albania ${ }^{19}$. The creation of the new state that uses its own national symbols and runs a separate policy of historical and cultural heritage has led to the creation of national identity of its inhabitants.

This process can be linked to the Politics of nation-building and state-building ${ }^{20}$. Both of the theories assume the intervention of external factors in the process of building the nation and the state. The concept of state-building is linked with development cooperation and the activity of third countries or international organizations in the post-conflict region ${ }^{21}$ (e.g. UN peacekeeping interventions or the intervention of US troops and associated countries and other stabilization missions). The concept of nation-building is defined as 'the use of armed force in the aftermath of the conflict, to ensure and support the transition towards democracy'22. In this context, these concepts overlap in meaning in everyday language and are frequently used interchangeably, however political science offers a clear distinction between nation-building and state-building. While the first concept draws attention to the aspect of the evolution of identity, the second relates to the creation of institutions and infrastructure of the state. Both terms describe the influence of the external forces to create state institutions and introduce mechanisms of political life based on the pattern that is used by these forces. Those actions might have taken various forms e.g. foreign investment, aid programs, military occupation or the introduction of a stabilization or humanitarian.

${ }^{18}$ In Albanian, Kosovar means an inhabitant of Kosovo. The Constitution of the Republic of Kosovo has no determination of the nationalities living in the state. The preamble is using - I Populli Kosovës, which means “The people of Kosovo." Kushtetutae e Republikës së Kosovës, http://www.gazetazyrtare.com/e-gov/index. php?option=com_content\&task=view\&id=130\&Itemid=54, (date accessed: 10.05 .2015$)$.

${ }^{19}$ Even though many Kosovars display the Albanian national flag in front of their homes, they often have never lived in the borders of the Albanian state. The black double-headed eagle plus communist star was also legal to be displayed by the Albanian minority in SFR Yugoslavia since 1968. Article 1. of Comprehensive Proposal for the Kosovo Status Settlement, United Nation S/2007/168/Add. 1. (26.03.2007) states that "Kosovo shall have is own symbols, including flag, seal and anthem, reflecting its multi-ethnic character" http://www. unosek.org/docref/Comprehensive_proposal-english.pdf, (date accessed: 03.09.2015).

${ }^{20}$ According to Charles Tilly: state-building, "State building provided for the emergence of specialized personnel, control over consolidated territory, loyalty, and durability, permanent institutions with a centralized and autonomous state that held the monopoly of violence over a given population”, Ch. Ti11 y, Western-State Making and Theories of Political Transformation, in: Ch. Tilly, G. Arndant (eds.), The Formation of National States in Western Europe, Princeton 1975.

${ }_{21}$ V. Fritz, A. R. Me n o c a 1, State-Building from a Political Economy Perspective: An Analytical and Conceptual Paper on Processes, Embedded Tensions and Lessons for International Engagement, 2007; Website of the Overseas Development Institute, http://www.odi.org/resources/details.asp (date accessed: 10.05.2015).

22 J. D o b b in s, Nation-Building: the Inescapable Responsibility of the World's Only Superpower, RAND Review, Vol. 27, no. 2/2003, p. 17. 
In the monograph The Politics of nation-building. Making Co-Nationals, Refugees and Minorities Harris Mylanos defines Politics of Nation-Building as 'Legitimate authority in modern national states is connected to popular rule, to majorities. Nation-building is the process through which these majorities are constructed ${ }^{23}$. He describe this process as a multilateral and interstate relation between the national homeland, external power and host state towards demands of the non-core group. The outcome of efforts by the non -core group can be featured as extermination (with inefficient or lack of support of external power), assimilation or accommodation. The endorsement of the external powers for the demands of non-core group, especially when the national homeland is in the alley with them results with the positive outcomes for the constructing majorities as a result of the struggle of the non-core group. Another factor, which has to be taken into account is the host's state of the foreign policy goals, which can be recognized into two main trends - status quo or revisionist. In the case of Kosovo we need to define the scenario as accommodation, where the majority is constructed as a result of support interstate relations, support of the external powers despite the revisionist foreign policy of Serbia.

The term 'nation-building' is often used by the politics commentator and journalist to describe the US Department of Defense 'stability operations' in the Balkan region, Middle East and Africa and refers to the providing logistics support in the building state infrastructure. This definition does not cover the entire semantic range which nation-building gained over the last five decades of the experience of the stabilization and the peace-building missions. The state infrastructure together with introducing agencies and international norm promotion can be defined interchangeably as politics of state - building. While the politics of nation-building can be described as a process through which governing elites strive to coincide the boundaries of the state and nation. In this meaning it can be called alternatively as national integration ${ }^{24}$.

\section{Norm - promotion, localisation and contestation}

The international standards and norms need to be translated from the global meaning into the local circumstances and necessity in the politics of the state-building and nation-building. In the post-war countries such norms as democracy, rule of the law, rights of minorities and free-market economy are transmitted by peacebuilding agents ${ }^{25}$. In the many of post-war states supported by stabilization or peacebuilding missions after 1989 the full catalogue of the international norms failed to be adopted in the full demand as the cause of the failure of the liberal norms or its limited success the local resistance to the actions of the peacebuilding agents should be emphasised ${ }^{26}$. The set of the measures, ac-

${ }^{23}$ H. Mylan os, The Politics of Nation- Building. Making Co-Nationals, Refugees and Minorities, Cambridge 2013, p. 20.

${ }^{24}$ H. Mylon as, The Politics..., p. 20.

25 R. Paris, Peacebuilding and the Limits of the Liberal Internationalism, International Security 22(2/1997), p. 54-89.

${ }^{26}$ O. R i c h mond, Becoming Liberal, Unbecoming Liberalism. Liberal-Local Hybridity via the Everyday as a Response to the Paradoxes of Liberal Peacebuilding, Journal of Intervention and Statebuilding 3(3/2010), p. 324-344. 
tions and intervention are often inappropriate and inadequate to the specifics of the region and its situation in the aftermath of the conflict. This line of argument highlights the decoy of the 'agents of the West' as the domestic liberal forces are often described and the problem of the liberal-local hybridity ${ }^{27}$. In the post-conflict regions some issues e.g. minority laws or the rule of the law are very urgent and fragile matters, very often need to be handle by external mediations, which peacebuilders are providing. A consensus is often almost impossible to be achieved and in the negotiation process each parties should be involved to give a sense of the representation of the interests. On the other hand after reaching a compromise the agents, which took part in the construction of the new rules might be recognized as traitors which have abandoned the common case. Of course the hybridity of the liberal-local case doesn't have its applications in every post-conflict case.

The diffusion of the international norms process in the post-war regions should be multi faced and it emerges the local context. It can goes beyond the hybridity of the liberal-local agents and their work in the process of the norm promotion and touch the traditional and indigenous system of the rules and practises $^{28}$. The third wave International Relation norm diffusion is offering a solution to mix liberal norms with the local tradition $^{29}$. This also answers the question why some norms are transferred successfully and materialise in domestic political culture. What is more it is also provides an interpretation of the way war-shattered societies relate to the liberal norm system introduced by peacebuilders. This approach refers to a three-stage international norm diffusion, norm-promotion, contestation and localization. This allows us to understand the entire range of different 'local meanings' of international norms and explains the strategy used by agents to promote the international norm system.

The promotion of norms is completed by the peacebuilders together with the local NGOs, the work of the foreign NGOs, projects funding and the presence of the foreign representations in the post-war countries. It is concentrated on explaining the liberal norms such as minority laws or democratic political institution and it focuses on the educational projects, cultural events and symbols together with promoting norms on the occasion of the investment in infrastructure. Contestation is a very significant part in the successful international norm diffusion process as this is the time in which choices are made, where norms can be transferred to the local law system. The agents in the process of contestation are local NGOs together with political elites. In this phase norms are translated into the 'local meaning', which would be acceptable to the people leaving in the country and accepted as their own system of laws and rules. Of course not every norm can be successfully transferred to the indigenous system and into the institution of public life in the administrative level hence the peacebuilders should co-work with the local NGOs and political elites to reach a compromise between the liberal norms and the local system. Depending on various local conditions and the work of peacebuilders the outcome of the norm diffusion can be norm rejections, localization or acceptance ${ }^{30}$.

\footnotetext{
${ }^{27}$ Ibidem.

${ }^{28}$ R. Mac Ginty, Indigenous Peace-Making Versus the Liberal Peace, Cooperation and Conflict 43(2)/2008, p. 139-163.

${ }^{29}$ A. A chary a, How Ideas Spread. Whose Norm Matter? Norm Localization and Institutional Change in Asian Regionalism, International Organization 58(2)/2004, p. 239-275.

${ }^{30}$ Ibidem, p. 239.
} 


\section{International norm diffusion - building democracy}

The international norm diffusion outcomes in the sphere of building institutions of democracy was a limited success. The NATO intervention in 1999 was aimed at stopping conflict between Kosovo Albanians, Kosovo Serbs, Serbian Government and the peacebuilders administration in the region significantly changed the political and social situation in the disputed territory. Even though the operation Allied Force operation had come to the end in June 1999 the conflict still was running its course, also after the declaration of independence in 2008 and during the international administration in the territory of Koso$\mathrm{vo}^{31}$. The beginnings of the normalization of Serbian-Kosovo relation were negotiations launched in 2011 and signing the Brussel Agreement in 2013, with the support of the European Union, NATO, the OSCE, and the United Nations ${ }^{32}$. The United Nations Mission in Kosovo is one of the largest initiatives per capita in the history of the organization both in terms of material and the number of mission personnel ${ }^{33}$. Under the supervision of UNMIK (United Nations Interim Administration Mission in Kosovo) Kosovo evolved from a one-party system to multiparty democracy and from a centrally directed to a market economy. In a state in which there there was no development democratic tradition, a legislation system based on a catalogue of the international norms and standards was introduced in the forms of multi-ethnicity and protection for the minority rights, the rule of law, equality of citizens before the law, respect for the human rights and freedoms and the constitutionality of the delegated legislation and free market economy ${ }^{34}$. The UNMIK mandate in 1999 was to administrate the legislative, executive and judicative functions in Kosovo and help to establish the successful democratic institution, which were planned to be able to take over the authority in Kosovo after the 'interim administration' would be finished. The promoted norms by UNMIK in the sphere of the democratic institution insist upon non-discrimination, visibility, professionalism, independence and impartiality ${ }^{35}$.

These principles have been applied inter alia in the organization system of the Assembly of Kosovo in which 100 seats are taken by the deputies from political parties according to the elections results and 20 seats are allocated for minorities. Of course in a newly established Republic, which is still in the process of political and economic transformation, there are still very significant cases of abuse of power and political corruption.

The process of diffusion of democratic standards in post-war Kosovo is a multilevel process, which involved many actors (international organizations, government of Kosovo, local administration and non-governmental organizations). This process can be understood as a sequence of the promotion of international standards, translating them into the local

31 See more: P. Marcinkow s ka, Kosowo jako suwerenne państwo. Teoria i praktyka, Warszawa 2016, p. 23-31.

${ }^{32}$ M. Perlec, N. R a shiti, Serbs Integration in Kosovo after the Brussels Agreement, http://balkansgroup.org/wp-content/uploads/2015/03/Serb-Integration-Kosovo-19-March-2015.pdf, p. 5. (date accessed: 02.06.2017).

${ }^{33}$ L. Gro $\beta$. The journey from global to local: norm promotion, contestation and localization in post-war Kosovo, Journal of International Relations and Development, Vol. 18 (3/2015).

${ }^{34}$ A summary was based on the Comprehensive Proposal for the Kosovo Status Settlement, United Nation S/2007/168/Add. 1. (26.03.2007), http://www.unosek.org/docref/Comprehensive_proposal-english.pdf, (date accessed: 03.09.2015).

35 L. Groß. The journey..., p. 314. 
meaning, choosing which international norms can be implemented in the domestic realm by agents (contestation of the norms) and the implementation of the system of legislation (location, acceptance or rejection) ${ }^{36}$. The international norm promotion process is carried out by the peacebuilders agents through various instruments such as financial incentive, coercion, capacity building, persuasion and argumentation ${ }^{37}$. The contestation of the norm also engaged local actors which are translating the international norms, transferring them together with the local context to the new meaning, which is coherent with the domestic discourse. This process is performed through discourses, framing, grafting and cultural selection $^{38}$. It is carried out on two levels - between peacebuilders and national elites in the first level and also between national elites - politicians and NGOs and local elites and local populations, who are making the final decision about norm adaptation. The localisation is understood as a materialisation of the international norms in the local law system. As Acharya explains the localization 'may start with the reinterpretation and re-representation of the outside norm, including framing and grafting, but it may extend into more complex process of reconstruction to make to make an outside norm congruent with a pre-existing local normative order ${ }^{339}$. Localization is not the only possible outcome of norm diffusion - norms can be accepted without translating and reframing or rejected as a whole ${ }^{40}$. In case of international norm diffusion process in Kosovo we observe - full materialisation of the norms in the local system - e.g. launching democratic institutions, national symbols as well as localization e.g. legislation system, free-market economy and rejections - minority laws and non-discrimination.

In the preamble to the Constitution of the Republic of Kosovo which entered into force on 15 June 2008 there was a conclusion of intention to fully participate in the Euro-Atlantic integration of the newly created republic ${ }^{41}$. The Constitution of the Republic of Kosovo was based on the plan of Martti Ahtisaari. In 2008 the new government appointment was supervised by UNMIK missions and public institutions. Furthermore a new official currency - the euro and the national symbols were established in the voting of the Assembly. These nationals symbols were selected through an international competition: flag showing a yellow outline of the state on a blue background with a towering six white stars and anthem - a song without words called 'Europe'. Non-governmental organizations (NGOs), with approximately 7,000 registered in the territory of the republic have played a major role in the process of the introduction of civil society standards in Kosovo. Their initiatives include almost every aspect of the public sphere.

Many European countries are abidingly present in Kosovo and the rest of the Western Balkans. An example of the norm-promotion by external forces is work of the German NGOs. German policy in the Kosovo during last years was focused on reconstruction, stabilization, consolidation of the rule of law and market economy, as well as a mem-

\footnotetext{
${ }^{36}$ A. A rc hary a, How ideas spread..., p. 239-275, L. Gro $\beta$. The journey..., p. 312-314.

${ }_{37}$ T. Börze 1, T. Risse, From Europeanisation to Diffusion: Introduction, West European Politics, 35(1/2012), p. 1-19.

${ }^{38}$ A. Archary a, How ideas spread..., p. 245.

${ }^{39}$ Ibidem, p. 244.

40 Ibidem.

${ }^{41}$ Kushtetutae e Republikës së Kosovës (15.06.2008), http://www.kushtetutakosoves.info/ (date accessed: 10.05.2015).
} 
ber state-building and is embedded in the notion of commitment to the EU enlargement policy ${ }^{42}$. The goals of German foreign policy in Kosovo are accomplished mostly by the German political foundations and their activities in the region, e.g. Heinrich-Böell Foundation, Friedrich Ebert Foundation, Friedrich Naumann Foundation for Freedom, Konrad Adenauer Foundation etc. The foundation are financed by the German federal budget and are targeted to promote international norms, German interest and European integration. These foundations offer a wide range of different programs, scholarships and other activities which are mostly focused in grafting civil society standards.

The Konrad Adenauer Foundation has its field in the every country of the Western Balkans region and offers scholarships programs and internships to Germany. It is covers the transferring the standards of the freedom, solidarity and justice by the educating and training young professionals and enhancing their technical and administrative performance. The office was opened in Kosovo in 2007 and is working in the field of free-media, supporting interethnic and interreligious dialogue, the European integration process, and political and civic education ${ }^{43}$.

Like the Konrad Adenauer Foundation, the Friedrich Ebert Foundation has a field office in every state of the Western Balkans. The Prishtina office was officially founded in 2000 and since then is committed to strengthening the civil society, democratically supporting local decentralisation and local government, promoting a socially just and sustainable economic development and strengthening labour relations by cooperating with trade unions and employers' organization and also supporting regional and international integration ${ }^{44}$.

The Heinrich-Böell Foundation has two offices in the Western Balkans of which the office responsible for Montenegro, Serbia and Kosovo has its office in Belgrade. Their activities are focused mostly on the field of democracy, education, culture, ecology, economy and European integration. The foundation places a particular emphasis on gender democracy, meaning social emancipation and equal rights for women and men and suitable development together with promoting green technology. Their main form of activities include providing knowledge to the different publications, bringing partners together, transferring knowledge and skills, providing space for wide range of seminars, meeting and debate ${ }^{45}$.

The Friedrich Naumann Foundation for Freedom is mostly focused on promoting democracy, the rule of law, free-market economy and political pluralism. It completes this mission through political education, consulting and political dialogue, organising debates, study trips and seminars. The Foundation also organizes liberal forums for debate, supporting start-ups and fostering closer relations between organisations in Kosovo and others European countries ${ }^{46}$.

42 J. Wa n n ing er, The Western Balkans: a touchstone for German and European foreign policy, Notes du Cerfa, no 130, May 2016, http://www.ifri.org/en/publications/notes-de-lifri/notes-cerfa/western-balkans-touchstone-german-andeuropean-foreign (date accessed: 09.12.2016).

${ }^{43}$ The Konrad Adenauer Foundation, http://www.kas.de/kosovo/en/about/ (date accessed: 10.12.2016).

${ }_{44}$ The Friedrich-Ebert-Stiftung Prishtina office, http://www.fes-prishtina.org/wb/pages/english/fes-inprishtina.php (date accessed: 10.12.2016).

45 The Heinrich-Böell Foundation, http://rs.boell.org/en/categories/foundation, (date accessed: 10.12.2016).

${ }^{46}$ The Friedrich Naumann Foundation, https://www.freiheit.org/content/kosovo, (date accessed: 10.12.2016). 
are many regional offices of the political NGOs from Europe and United States in the field of democracy, as well as free-market economy, the information society, non-discrimination, education, culture and humanitarian aid are located in the region of Western Balkans and Kosovo. The other activities held by foreign NGOs are partnerships with local organizations in the particular projects supported by international funds such as the International Visegrad Fund, European Fund for the Balkans, the Balkans Arts \& Culture Fund, Austrian Development Agency, Pontis Foundation, European Union structural funds and many others. These agencies pursue activities from the perspective of international norm promotion in the region (information, publications, debating, conferences, meeting, networking, capacity building, persuasion and argumentation etc.) and norm contestation (translating, reframing, grafting, cultural selection). Support of international organizations, international specialists and support of the international NGOs are aimed to assist the government in the localization of the law, dealing with the post-conflict problems and promote good governance standards. In the war-shattered regions political elites have to deal with the problems of building cohesive communities replacing different conflict parties.

The newly appointed government introduced a policy of evolution of national identity from Albanians to Kosovo. For this purpose, they used strongly accented national symbols and the activities and funding sources of the NGOs. The Nation of the Republic of Kosovo had to evolve towards Western standards - has been re-designed. Policy of nation-building implies the need to create national symbols and myths, highlighting important anniversaries, the introduction of national days and places of worship, building monuments and giving new patronage to the public places ${ }^{47}$. The biggest challenge in the process of designing a new nation was the creation of a cohesive community in place of a heterogeneous community ${ }^{48}$. This process was conducted by the management of relationships between local initiatives and non-governmental organizations and international organizations. Anna Ohanyan raises the thesis that it is the NGO sector that was the largest recipient of international aid in the post-conflict regions ${ }^{49}$. Microfinancing NGOs and social initiatives by international organizations (the author focuses mainly on the United Nations and the World Bank) is an instrument for achieving the interests of the donors after 1999 and this mechanism was also applied in Kosovo ${ }^{50}$.

The hardest challenge in the norm contestation in a war-shattered territory is the deep polarization in the society between groups which stood on the different sides during the conflict as well as the different conflict goals of these two parties which has to be taken into consideration when talking about norm diffusion in the aftermath of war ${ }^{51}$. Kosovo should be characterized by deep polarization between Kosovo-Albanians and Koso-

${ }^{47}$ A. D. S m ith, State-Making and Nation-Building, in: J. Hall (ed.), States in History. Oxford 1986, p. $228-263$.

${ }^{48}$ H. Mylonas, Assimilation and its Alternatives: Caveats in the Study of Nation-Building Policies, [in:] A. Lawrence, E. Chenoweth (ed.) Rethinking Violence: State and Non-state Actors in Conflict, Cambridge 2010, p. 83-156.

${ }^{49}$ A. Ohany an, NGOs, IGOs, and the Network Mechanisms of Post-Conflict Global Governance in Microfinance, New York 2008, p. 1.

${ }^{50}$ Ibidem, p. 145-170.

51 L. Groß. The journey..., p. 315-316. 
vo-Serbs, which has produced a long lasting division among the society. This polarization is still shaping the politics of Kosovo, especially since even information and media are deeply ethicized, Albanian as a reference uses Albanian language media from the Prishtina and Serbs refers mostly to Belgrade TV and radio. In such conditions one pattern of the norm contestation cannot exist, when two groups in the society are characterized by different goals of the inter and external politics. The conflict in Kosovo was caused by different long term goals of the intra-state politics between two parties living in the region - ethnic Albanians striving towards an independent state, and ethnic Serbs aimed Kosovo to remain part of Serbia. Even today because of this deep division the Kosovo state's legitimacy, national symbols etc. are oppugn by Kosovo-Serbs ${ }^{52}$. This different conflict goals permeate the contestation of the international norms and result in the same norms being accepted by part of the society and rejected by other party, or localized in the different dimension. 'Local meaning' in the post-war society is still shaped by the different conflict goals and work of peacebuilders is not able to completely erase this division.

\section{Conclusion}

According to the theories of Harris Mylanos ${ }^{53}$ and Rogers Brubaker ${ }^{54}$ the processes of state-building and nation-building involves the following entities: nationalizing state, national homeland and external power - international organizations and superpowers. This determines the success or failure of the demands of a minority group (non-core group), or about the establishment of their own state and deciding the relationship between these three actors.

In the case of Kosovo this scenario ended successfully as a result of the support of international organizations and the United States for the claims of the Albanians in Kosovo, in support of Albania and the weak position of the interests of Serbia. The scenario started within the military intervention of NATO troops, the establishment of a stabilization missions and finally the recognition of the declaration of independence by the Republic of Kosovo in 2008. The main importance for the success of the scenario had the aspect of external forces (among others UNMIK, KFOR, EULEX and international NGOs) as a causative factor in the design of the new nation in Europe.

Currently, the Republic of Kosovo is recognized as an independent state by most countries in the European Union and NATO. The European Union, however, has not released an official statement, and left the decision to recognize the declaration of independence to the member states. However, in negotiations with Serbia, the organization has set a clear requirement to recognize the independence of the Republic. Apart from Serbia, Kosovo is not recognized among others by Russia, China, Ukraine, Slovakia, Spain, Romania, Cyprus, Kazakhstan and other countries, especially those that are threatened by separatist movements. Russia, which is Serbia's traditional ally demanded even the con-

52 D. Papadimitriou, P. P etrov, Whose Rule, Whose Law? Contested Statehood, External Leverage and European Union's Rule of Law Mission in Kosovo, Journal of Common Market Studies, 50 (5)/2012, pp. 746-763.

${ }^{53}$ H. Mylonas, The Politics..., p. 18-22.

${ }^{54}$ R. Brubacker, Nationalism Reframed, Cambridge 1996, p. 55-76. 
vening of the Security Council meeting on Kosovo. UN Secretary-General Ban Ki-moon said that the UN Mission in Kosovo will continue to implement its mandate in accordance with maintaining Resolution 1244 of 1999 instructing the United Nations administration of this region in force. In the face of the opposition of Russia and China, Kosovo hasn't been formally recognized by the UN as an independent state.

The war-shattered territory has had to deal with many problems as discrimination, a weak-economy, lack of a democratic institution, deep polarization in the society and finding a new identity. The activities held by the peacebuilders and international agents in the region were aimed at helping in the transition process from the one-party system to political pluralism and from a centrally directed to a free-market economy. Additional important factors include international NGOs and external fund was supporting civil society and non-discrimination policy together with the good-practise and knowledge transmissions.

The diffusion of the international norm process can be understood as a sequence of the norm-promotion, contestation and localization and is held with the support of the external organizations and peacebuilders, local political elites, local NGOs, administration and finally the local population which is deciding about norm localization, acceptance or rejection. International norms need to be translated to the 'local meaning' to be able to materialize in the local system law. Not every norm can be successfully transfered to the local system, in the case of Kosovo we can also see that despite of the immense support of the peacebuilders and other nation-building agents, the norm diffusion process did not end successfully in every sphere. We can evaluate the democratic institution launching as a limited success (despite the problems of the transformation period), introducing a cohesive community in place of the conflict-divided society, non-discrimination and implementing and obeying minority laws are the aspects which still require tremendous work and time. The work of the peacebuilders agents - especially NGOs in this area is very important. The polarization in the society divided by the long-lasting conflictual situation requires delicate measurements and a possible generation change. Nation-building in the sphere of implementing new national symbols without a negative connotation for any of the conflict parties is important but is not sufficient to resolve the widespread division in the Kosovo society.

\section{Bibliography}

Published sources:

Comprehensive Proposal for the Kosovo Status Settlement, United Nation S/2007/168/Add. 1. (26.03.2007), Website of the UNOSEK, http://www.unosek.org/docref/Comprehensive_proposal-english.pdf,

International Court of Justice 2010-07-22, http://www.icj-cij.org/docket/files/141/15987.pdf

International Criminal Tribunal for the former Yugoslavia, IT020214, http://www.icty.org/x/cases/ slobodan_milosevic/trans/en/020214IT.htm

Krieger H., (e-.). The Kosovo Conflict and International Law: An Analytical Documentation 1974-1999, Cambridge 2012.

Kushtetutae e Republikës së Kosovës(15.06.2008), Website: Gazetta Zyrtare, http://www.gazetazyrtare.com/e-gov/index.php?option=com_content\&task=view\&id=130\&Itemid=54, Letter dated 
26 March 2007 from the Secretary-General addressed to the President of the Security Council, Addendum, Comprehensive Proposal for the Kosovo Status Settlement, United Nations Security Council, 26 March 2007, http://www.unosek.org/docref/Comprehensive proposal-english.pdf The Charter of the United Nation, San Francisco 26 June 1945, http://www.un.org/en/charter-united-nations/index.html

Reports:

Fritz V., Menocal A. R., State-Building from a Political Economy Perspective: An Analytical and Conceptual Paper on Processes, Embedded Tensions and Lessons for International Engagement, 2007; Website of the Overseas Development Institute, http://www.odi.org/resources/ details.asp

Independent International Commission on Kosovo, The Kosovo report: conflict, international response, lessons learned, New York 2000.

Perlec M., Rashiti N., Serbs Integration in Kosovo after the Brussels Agreement, http://balkansgroup.org/wp-content/uploads/2015/03/Serb-Integration-Kosovo-19-March-2015.pdf

Wanninger J., The Western Balkans: a touchstone for German and European foreign policy, Notes du Cerfa, no 130, May 2016, http://www.ifri.org/en/publications/notes-de-lifri/notes-cerfa/ western-balkans-touchstone-german-andeuropean-foreign

Monography:

Arndant G., Tilly Ch. (eds.), The Formation of National States in Western Europe, Princeton 1975.

Brubacker R., Nationalism Reframed, Cambridge 1996.

Gibas-Krzak D., Serbsko-albański konflikt o Kosowo w XX wieku: uwarunkowania, przebieg, konsekwencje, Toruń 2009.

Hall J. (ed.), States in History, Oxford 1986.

Jenne E. K., Ethnic Bargaining: The Paradox of Minority Empowerment, New York 2007.

Malcolm N., A Short History of Kosovo, New York 1999.

Malendowski W., (ed.), Zbrojne konflikty i spory międzynarodowe u progu XXI wieku. Wrocław 2003.

Marcinkowska P., Kosowo jako suwerenne państwo. Teoria i praktyka, Warszawa 2016.

Marszałek M., Sojusznicza operacja „Allied Force”: przebieg - ocena-wnioski. Torun 2009.

Mylanos H., The Politics of Nation-Building. Making Co-Nationals, Refugees and Minorities, Cambridge 2013.

Ohanyan A., NGOs, IGOs, and the Network Mechanisms of Post-Conflict Global Governance in Microfinance, New York 2008.

Prentiss C. R., (ed.), Religion and the Creation of Race and Ethnicity: An Introduction, New York 2003.

Smith A. D., Ethnic Origins of the Nations, Oxford 1988.

Articles:

Acharya A., How Ideas Spread. Whose Norm Matter? Norm Localization and Institutional Change in Asian Regionalism, International Organization 58(2/2004).

Börzel T., Risse T., From Europeanisation to Diffusion: Introduction, West European Politics, $35(1 / 2012)$.

Dobbins J., Nation-Building: the Inescapable Responsibility of the World's Only Superpower, RAND Review, Vol. 27, (2/2003).

Gro $\beta$ L., The journey from global to local: norm promotion, contestation and localization in post-war Kosovo, Journal of International Relations and Development, Vol. 18 (3/2015).

Korzeniewska-Wiszniewska M., Geneza konfliktu serbsko-albańskiego w Kosowie w latach 1968 -1998 na tle wewnętrznej polityki jugosłowiańskiej - próba analizy, [in:] Studia z dziejów Rosji i Europy Środkowo-Wschodniej, v. XLIII, P. Łossowski (ed.), Warszawa 2008. 
Lubonja F., Neocolonialism and Responsibility, The Western Presence in the Balkans, Eurozine (14/02/2002), http://www.eurozine.com/articles/2002-02-14-lubonja-en.html, (date accessed: 14.03.2014).

Mac Ginty R., Indigenous Peace-Making Versus the Liberal Peace, Cooperation and Conflict 43(2/2008).

Papadimitriou D., Petrov P., Whose Rule, Whose Law? Contested Statehood, External Leverage and European Union's Rule of Law Mission in Kosovo, Journal of Common Market Studies, $50(5 / 2012)$.

Paris R., Peacebuilding and the Limits of the Liberal Internationalism, International Security 22(2/1997).

Richmond O., Becoming Liberal, Unbecoming Liberalism. Liberal-Local Hybridity via the Everyday as a Response to the Paradoxes of Liberal Peacebuilding, Journal of Intervention and Statebuilding 3(3/2010).

Rogel C., Kosovo: Where It All Began, International Journal of Politics, Culture, and Society, Vol. 17, $(1 / 2003)$.

Katarzyna Kropiak

The Politics of Nation-Building in Kosovo after 2008

\section{Summary}

The process of diffusion of international norms and democratic standards in the post-war Kosovo is a multilevel process which involved many actors (international organizations, the government of Kosovo, local administration and non-governmental organizations). This process can be understood as a sequence of the promotion of international standards, translating them into local meaning and choosing which international norms can be implemented in the domestic realm by agents (contestation of the norms) and the materialization of the norm in the system of legislation (location, acceptance or rejection). In this case for example, the promotion of international standards can be considered to present the plan of Martti Ahtisaari (Comprehensive Proposal for the Kosovo Status Settlement) in February 2007, the operations and activities of the UNMIK mission, ICR (International Civilian Representative for Kosovo) and ICO (International Civilian Office). By contestation standards should be understood as developed from the international standards in the local discourse by peacebuilding agents and locations - as decision and choice as to which standards should be implemented into the system of national legislation. In the case of Kosovo, not every international standard was transferred successfully to the local realm, while launching democratic institutions can be understood as a limited success, the minority law and non-discrimination policies still require a lot of work to be done.

Key words: Nation-Building, State-Building, Norm-Promotion, International Norms, NGOs. 